\title{
Inhibition of rats extramedullary liver erytropoiesis by hyperbaric oxygen therapy ${ }^{1}$
}

\author{
Inibição da eritropoese extramedular hepática \\ pela oxigenoterapia hiperbárica
}

\author{
Ricardo Costa-Val ${ }^{2}$, Tarcizo Afonso Nunes ${ }^{3}$, Roberto Carlos de Oliveira e Silva ${ }^{4}$, Antônio Francisco de Souza ${ }^{5}$, Irene \\ Edith de Puy e Souza ${ }^{6}$, Tatiana Karina de Puy e Souza ${ }^{6}$ \\ 1. Research performed at Post-Graduation Program in Surgery, Faculty of Medicine, Federal University of Minas Gerais (UFMG), Brazil. \\ 2. PhD, Head Division, Department of Surgery, Vale do Rio Verde University (UNINCOR), Brazil. \\ 3. PhD, Associate Professor, Department of Surgery, Faculty of Medicine, UFMG, Brazil. \\ 4. PhD, Volunteer Faculty, Department of Surgery, Faculty of Medicine, UFMG, Brazil. \\ 5. PhD, Associate Professor, Department of Pathology, Institute of Biological Sciences, UFMG, Brazil. \\ 6. Master, Associate Professor, Department of Gynecology and Obstetrics, Faculty of Medicine, UFMG, Brazil. \\ 7. Graduate student, Faculty of Medicine of Barbacena (UNIPAC), Minas Gerais, Brazil.
}

\begin{abstract}
Purpose: To research the hyperbaric oxygen therapy effects on rats' livers and spleens. Methods: 30 adult male Hotzman rats were used, being randomly distributed, by raffle, into 2 groups of 15 animals each: group 1 - control; group 2 - hyperbaric oxygen therapy. Group-2 animals underwent hyperbaric oxygen therapy for 120 minutes daily, 90 minutes of which were under pressure of 2.5 atmospheres. The first and last 15 minutes were used for gradual compression and decompression, respectively, for 20 days in a row. The livers and spleens of the animals from the two groups were taken out for histologic examination, on the day after the end of hyperbaric oxygen therapy in group 2 animals. Liver and spleen histologic changes of the animals from the two groups were compared by using Fisher exact test. $P<0.05$ was regarded as a significant difference. Results: The only change in liver and spleen histology was the significant reduction in hepatic extramedullary erythropoiesis in the animals that underwent hyperbaric oxygen therapy $(p<0.05)$. Conclusion: Hyperbaric oxygen therapy reduces hepatic extramedullary erythropoiesis in rats and doesn't jeopardize the other liver and spleen structures.
\end{abstract}

Key words: Hyperbaric oxygen. Erythropoiesis. Liver.

\section{RESUMO}

Objetivo: Pesquisar os efeitos da oxigenoterapia hiperbárica sobre o fígado e baço de ratos. Métodos: Foram utilizados 30 animais machos adultos da espécie Holtzman, distribuídos aleatoriamente e por sorteio em dois grupos de 15 animais cada, assim designados: grupo 1 - controle; grupo 2 - oxigenoterapia hiperbárica. Os animais do grupo 2 foram submetidos à oxigenoterapia hiperbárica por 120 minutos ao dia, sendo 90 minutos sob pressão de 2,5 atmosferas e 15 minutos iniciais e finais para a compressão e descompressão gradativa, respectivamente, em 20 dias consecutivos. Os fígados e baços dos animais dos dois grupos foram retirados para exame histológico, no dia seguinte após o término da oxigenoterapia hiperbárica nos animais do grupo 2. Compararam-se as alterações na histologia do fígado e baço entre os animais dos dois grupos empregando-se o teste exato de Fisher, considerando diferença significante o valor de $p<0,05$. Resultados: A única alteração na histologia dos fígados e baços foi a redução significativa da eritropoiese extramedular hepática nos animais submetidos a oxigenoterapia hiperbárica. $(p<0,05)$ Conclusão: A oxigenoterapia hiperbárica reduz a eritropoiese extramedular hepática em ratos e não compromete as demais estruturas do fígado e do baço.

Descritores: Oxigenação hiperbárica. Eritropoese. Fígado. 


\section{Introduction}

Hyperbaric oxygen therapy has been able to improve the evolution of animals and human beings with several diseases, in the physiopathologies of which there is triad, hypoxia, ischemia and reperfusion. Its applyance and indication in the treatment of several diseases are scientifically assured. It can even be used with specific diseases, like peripheral vascular diseases ${ }^{(1-4)}$. Nevertheless, there is a vast field in the medical area in which its usefulness and unfavorable effects are still unknown, and this stimulates clinical and experimental studies, controlled in vitro or in vivo to evaluate the desirable effects and the possible complications ${ }^{(2 ; 5-9)}$. This study aimed to research hyperbaric oxygen therapy effects on rats' livers and spleens, through histologic analysis.

\section{Methods}

This study respected COBEA's (Brazilian College of Animal Experimentation) ethical principles and was approved by the Federal University of Minas Gerais (UFMG) Medicine School Surgery Department Departmental Chamber. 30 male Holtzman rats were used in the study - They were kept in appropriate cages, exposed to light in regular cycles of 12 hours and fed with industrial feed (Nuvilab $\mathrm{CR}_{1}{ }^{\circledR}$, Nuvital Laboratory and ad libitum water in all phases of the study. The animals were randomly distributed, by raffle, in two groups:

1. Group 1 - Control - 15 animals that didn't undergo procedures;

2. Group 2 - Hyperbaric oxygen therapy - 15 animals that underwent hyperbaric oxygen therapy.

\section{Hyperbaric oxygen therapy}

The one-patient hyperbaric chamber (model BLKS 303 MK, Moscow) approved for use in Brazil by the National Agency of Sanitary Watch was utilized. Hyperbaric oxygen therapy was applied to Group 2 animals, using oxygen at $100 \%$ under pressure of 2.5 atmospheres, for 90 minutes, for 20 days in a row with regular intervals of 24 hours. The total duration of each session was of 120 minutes, as 15 minutes were used for gradual compression and 15 minutes were used for gradual decompression.

\section{Death of animals and removal of organs}

Groups 1 and 2 animals were killed by ether inhalation, 24 hours after the end of hyperbaric oxygen therapy, which the animals from group 2 underwent. Livers and spleens were removed after the separation of vascular pedicles and adjacent ligaments. Those organs were manually washed in current water until blood ran off; they were then fixed in formaldehyde $10 \%$.

\section{Histologic analysis}

Livers and spleens were processed in paraffin blocks, longitudinally sliced in microtome gauged for $5 \mu \mathrm{m}$ and stained with hematoxylin and eosin, by the use of light microscopy. Liver and spleen histologic changes like thrombosis in hepatic, portal and centrilobular veins, hepatocytes necrosis, changes in Kupffer cells, hepatic extramedullary erythropoiesis, red pulp congestion and hemosiderosis were researched.

\section{Studied variables}

Liver and spleen histologic changes of the group of animals that underwent hyperbaric oxygen therapy were compared with the control group by using Fisher Exact Test, considering a significance level of $5 \%(p<0.05)$.

\section{Results}

The histologic study of livers and spleens of the animals that underwent hyperbaric oxygen therapy (group 2) showed a significant reduction of hepatic extramedullary erythropoiesis in comparison with the control group (group 1) $(p<0.05) 2$ (Table 1 and Figures 1 e 2 ). The other changes that were researched weren't found.

TABLE 1 - Comparison of animals from groups 1 and 2 regarding hepatic extramedullary erythropoiesis

\begin{tabular}{lllll}
\hline Extramedullary & \multicolumn{2}{c}{ Group 1 } & \multicolumn{2}{c}{ Group 2 } \\
erythropoiesis & $\mathbf{N}$ & $\mathbf{\%}$ & $\mathbf{n}$ & $\mathbf{\%}$ \\
\hline Marked & 15 & 100.0 & 0 & 0.0 \\
Scarce & 0 & 0.0 & 15 & 100.0 \\
\hline TOTAL & $\mathbf{1 5}$ & $\mathbf{1 0 0 . 0}$ & $\mathbf{1 5}$ & $\mathbf{1 0 0 . 0}$ \\
\hline
\end{tabular}

Note: $p<0.001$ ( $p$ value refers to Fisher exact test) 


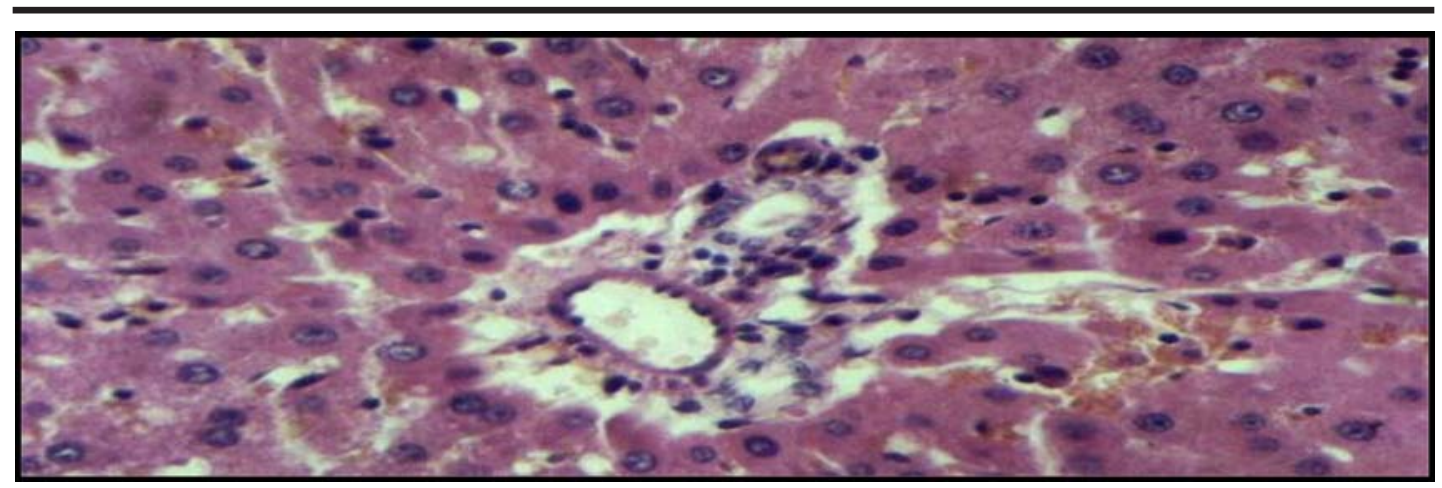

FIGURE 1 - Microphotography of liver histology through light microscopy of a group 1 animal. Areas of extramedullary erythropoiesis in porta (periportal) space are observed (400X)

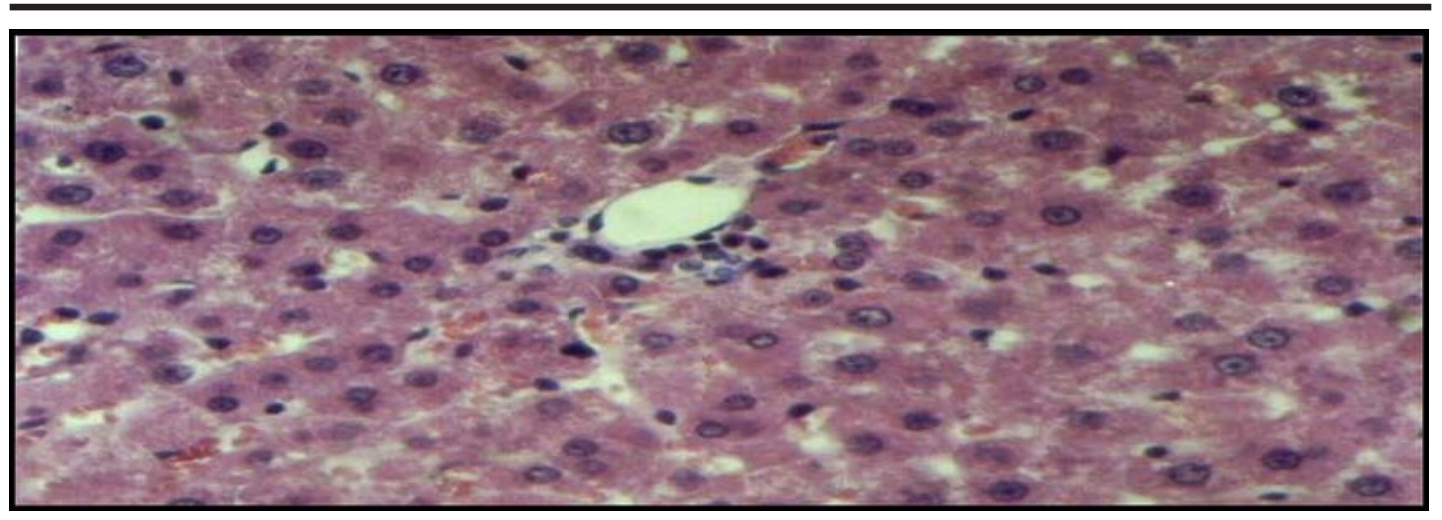

FIGURE 2 - Microphotography of liver histology through light microscopy of a group 2 animal. A great reduction of extramedullary erythropoiesis in porta (periportal) space, in comparison with Figure 1, is noticed. Coloring by hematoxylin-eosin (400X)

\section{Discussion}

Experience with hyperbaric oxygen therapy in Brazil started in Rio de Janeiro with Álvaro Ozório in 1940, in the treatment of patients with soft parts infection ${ }^{(7)}$. Hyperbaric oxygen therapy consists of intermittent inhalation of oxygen at $100 \%$, with a pressure of over one atmosphere. The current protocols recommend the implementation of 120-minute sessions and pressure between two and three atmospheres. Higher pressures are necessary in the treatment of decompressive disease and air embolias, reaching six atmospheres ${ }^{(5-10)}$. The main hyperbaric oxygen therapy favorable effects are the following:

a bigger input of oxygen to hypotoxic tissues; reactivation of humoral and cellular activity (macrophages, plasmacytes, fibroblasts, osteoclasts); stimulus to angiogenesis, with formation of granulation tissues; potentiation of some kinds of antibiotics and reduction in cicatrization time ${ }^{(5-7)}$.

The main hyperbaric oxygen therapy complications described are: pneumothorax, otitis media, gasous embolia, ocular fibroplasia and transitory reduction of pulmonary expiratory capability, which are related to secondary effects in organs and tissues that are susceptible to intracavitary pressure differences.
Although harmful effects of this therapy on human viscera haven't been described, the exposition to high pressures of $\mathrm{O}_{2}$ for a long period of time may decrease central nervous system threshold and cause convulsive crises. So the exposition to $\mathrm{O}_{2}$ at the pressure of 2.5 atmospheres in intermittent sessions of 90 to 120 minutes was defined as the ideal pattern. Complications to fetuses of experimentation animals and of humans due to the use of hyperbaric oxygen therapy weren't observed either ${ }^{(5,8 ; 12,13)}$. The Federal Medicine Council, in a publication in the Union Official Journal - 1995 regulated the use of hyperbaric oxygen therapy as a therapeutic procedure with scientific bases and clinical indications that are at the doctor's exclusive discretion in the following diseases: decompressive disease (usually divers'); gasous embolia; traumatic embolias by the air; serious intoxications by carbon monoxide or smoke inhalation; cyanide or hydrocyanic by product poisoning; gasous gangrene; Fournier syndrome; cellulites; fasciitises; myositises; traumatic acute ischemias; compartmental syndrome; docked extremities reimplantation; acute vasculitides of allergic or medicamentosus etiology or caused by arachnida, ophidia and insects toxins; electric and thermal burns; 
refractory lesions, such as skin ulcers; decubitus eschars; auto-immune vasculitides; suture dehiscences; lesions on the skin caused by irradiation, osteomyelitides, acute anemia, in cases of blood transfusion impossibility and cerebral abcess ${ }^{(7,8,14)}$. However, further researches are necessary in order to evaluate oxygen therapy validity for other diseases and the side effects of this therapeutics ${ }^{(9)}$. Hyperbaric oxygen therapy has also been used in several animal research models, with expressive results in various diseases ${ }^{(2-4)}$. Using this therapy with rats that underwent hepatic vein ligature, It was noticed a reduction in the animals' mortality and a significant attenuation of deleterious effects on liver and spleen, assessed by histology ${ }^{(11)}$. Erythropoiesis is by definition the process in which red cells are produced by bone marrow. In human beings, primitive red cells production happens in vitelline sac during embryonic phase but is transferred to liver during the first gestation trimester. Meanwhile, a smaller amount of erythrocytes is created in spleen and lymphatic nodes. In gestation final phase and after birth, erythrocytes are produced solely by bone marrow, although there are in liver small areas that are able to perform erythropoiesis. Extramedullary erythropoiesis isn't exclusive to human beings. It was observed in rats and other smaller mammals. All situations that decrease the oxygen amount usually transported to tissues, for instance anemia, longstanding cardiac insufficiency, bronchopulmonary diseases (emphysema, bronchitis, arteriovenous derivations) and staying at high altitudes increase erythrocyte production speed $^{(15-17,18}$. Hypoxia is a fundamental stimulus to erythropoiesis, but without a direct action on bone marrow. Stimulus is indirect, through the production of erythropoietin, which is a floating hormone from the glycoprotein group. Erythroprotein starts to be formed in a few minutes and reaches its top production in about 24 hours. However, almost no red blood cell appear in circulating blood before five days ${ }^{(17-19)}$. When this hormone lacks hypoxia has a practically null effect on the capability of arousing red cell production. When the system that involves erythropoietin is working properly, hypoxia causes a marked increase in its serum concentration, and therefore raises red cell production until hypoxia is corrected. ${ }^{(20)}$

Experimental studies, many of which carried out with rats, also showed that hypoxia is a powerful stimulus to several reactions in organism. Even though it still isn't totally understood, it is known that hypoxia is capable of activating cellular transcription and posttranscription mechanism by means of reactions that involve messenger RNA. It also acts as an indirect factor for angiogenesis and gene activation, besides being able to cause protein synthesis activation in rats livers ${ }^{(19-22)}$. The extramedullary erythropoiesis reduction observed by hepatic histology of the animals that underwent hyperbaric oxygen therapy in this study can be explained by the physiologic principles described. When those animals were exposed to an environment that was rich in oxygen, characterized by transitory hyperoxia, there was probably an inhibition of erythropoietin production and of hepatic extramedullary erythropoiesis. This fact shows hyperbaric oxygen therapy influence on organism organs and tissues, and perspectives to new researches are opened.

\section{Conclusion}

Hyperbaric oxygen therapy caused a hepatic extramedullar erythropoiesis decrease, without changing the other liver and spleen structures.

\section{References}

1. Nylander, G; Lewis, D; Nordström, H; Larsson, J. Reduction of postischemic edema with hyperbaric oxygen. Plast Reconstr Surg 1985; 76 (4):596-601.

2. Edwards, R.J; Im, M.J; Hoopes, J.E. Effects of hyperbaric oxygen preservation on rat limb replantation: a preliminary report. Ann Plast Surg 1991;27(1):31-5.

3. Zamboni, W.A; Roth, A.C; Russel, R.C; Graham, B; Suchy. H; Kucan, O.J. Morphologic analysis of the microcirculation during reperfusion of ischemic skeletal muscle and the effect of hyperbaric oxygen. Plast Reconstr Surg 1993;91(6):1110-23.

4. Chen, M.F; Swn, U; Shyr M-H. Hyperbaric oxygen pretreatment attenuates reperfusion injury. Liver 1998;18(2):110-6.

5. Grim, P.S; Gottlieb, L.J; Boddie, A; Baston, E. Hyperbaric oxygen therapy. JAMA 1990; 263(16):2216-25.

6. Costa-Val, R; Silva, R.C.O; Nunes, T.A; Souza, T.K.P. O papel da oxigenoterapia hiperbárica na doença vascular periférica. J Vasc Bras 2003;2(3):177-82.

7. Marcondes, C.M.; Lima, E.B. A oxigenoterapia hiperbárica como tratamento complementar das úlceras de membros inferiores - parte I. Rev Angiol Cir Vasc 2003;12(2):54-60.

8. Lima, E.B; Martins, A.C.G; Bernades, C.H.A. Uso da câmara hiperbárica no tratamento do pé diabético. Rev Angiol Cir Vasc 2001;10(1):11-4.

9. MAFFEI FHA. Oxigenoterapia Hiperbárica. - editorial J Vasc Bras. 2003;2(3):169.

10. Sousa, J.G.A. Inalação de oxigênio em meio hiperbárico. Rev Angiol Cir Vasc 2002;11(4):180-7.

11. Costa-Val, R; Nunes, T.A; Silva, R.C.O; Souza, T.K.P. Efeitos da oxigenoterapia hiperbárica em ratos submetidos à ligadura das veias hepáticas: avaliação da mortalidade e da histológia do fígado e baço. Acta Cir Bras 2006.21(1);51-6. 
12. Thorsen, E; Aanderud, L; Aasen, T.B. Effects of a standard hyperbaric oxygen treatment protocol on pulmonary function. Eur Respir J 1998;12:1442-5

13. Tomaszewski, C.A.; Thom, S.R. Use of hyperbaric oxygen in toxicology. Emerg Med Clin North Am 1994;12(2):437-59.

14. Lima EB, Bernardes CHA, Martins ACG, Marcondes CM. O papel da oxigenoterapia hiperbárica no tratamento da gangrena gasosa clostridiana e da fasciite necrotizante. J Vasc Bras. 2003;2(3):220-4;

15. Dessypris, E.N. Erythropoiesis. In: Lee, G.R; Bithel, T.C; Foerster, J; Athens, J.W; Lukens, J,N. Wintrobe's Clinical Hematology. 9a. edição. Lea \& Febiger, Malvern, Pennsylvania, 1993: cap.6;134-57.

16. White, M.J.; Heckler, F.R. Oxygen free radicals and wound healing. Clin Plast Surg. 1990;17(3):473-84.

17. Baumann, R.; Dragon, S. Erythropoetin and red cells function in vertebrate embryos. Eur $\mathrm{J}$ Clin Invest
2005;35(3):2-12.

18. Kendall, R.G. Erythropoetin. Clin Lab Hem 2001;23(2):71-80.

19. Smith, K.; Marshall, J.M. Physiological adjustments and arteriolar remodeling within skeletal muscle during acclimation to chronic hypoxia in the rat. $\mathrm{J}$ Physiol 1999;521(1):61-72.

20. Deveci, D.; Marshall, J.M.; Egginton, S. Chronic hypoxia induces prolonged angiogenesis in skeletal muscles of rat. Experimental Physiol 2002;87(3):287-91.

21. Miralles, C.; Agusti, A.G.N.; Aubry, C.; Sanchez, J.C.; Walzer, C.; Hochstrasser, D.; Busquets, X. Changes induced by oxygen in rat liver protein identified by high-resolution two-dimensional gel electrophoresis. Eur J Biochem 2000;267(17):5580-4.

22. Schinh, S-C.; Claffey, K.P. Hypoxia mediated regulation of gene expression in mammalian cells. Int J Experimental Pathol 1998; 79(6): 347-57.

\section{Correspondence:}

Tarcizo Afonso Nunes

Rua Professor Estevão Pinto, 637/1104

30220-060 Belo Horizonte-MG Brazil
Conflict of interest: none Financial source: none

Received: November 24, 2006

Review: December 18, 2006

Accepted: January 12, 2007

\section{How to cite this article:}

Costa-Val R, Nunes TA, Oliveira e Silva RC, Souza AF, Souza IEP, Souza TKP. Inhibition of rats extramedullary liver erytropoiesis by hyperbaric oxygen therapy. Acta Cir Bras. [serial on the Internet] 2007 Mar-Apr;22(2). Available from URL: http://www.scielo.br/acb 